\title{
Maternal and neonatal seroprevalence of Hepatitis B surface antigen (HBsAg) in Tripoli, Libya
}

\author{
Hamida El-Magrahe ${ }^{1}$, Abdul Rahaman Furarah ${ }^{2}$, Kheiria El-Figih², Sued El-Urshfany ${ }^{3}$, \\ Khalifa Sifaw Ghenghesh ${ }^{2}$ \\ ${ }^{1}$ Faculty of Sciences, Al-Fateh University, Tripoli, Libya \\ ${ }^{2}$ Faculty of Medicine, Al-Fateh University for Medical Sciences, Tripoli, Libya \\ ${ }^{3}$ Tripoli Medical Center, Tripoli, Libya
}

\begin{abstract}
Background: Pregnant women with Hepatitis B virus HBV represent a major reservoir of the virus in the community. Data regarding the prevalence of HBV in pregnant women and maternal transmission of the virus in Libya are lacking.

Methodology: Hepatitis blood samples from 1,500 pregnant women and 1,500 cord blood samples of their neonates delivered at Tripoli Medical Center, Tripoli, were tested for HBsAg by ELISA technique. HBsAg-positive samples were also tested for HBeAg.

Results: HBsAg was detected in $1.5 \%(23 / 1,500)$ pregnant women and in $0.9 \%(14 / 1,500)$ neonates. Although HBsAg was detected at higher rate in pregnant women aged $>25$ years $[1.8 \%(22 / 1,235)]$ than in pregnant women aged < 25 years $[0.4 \%(1 / 265)]$, the difference was not statistically significant $(\mathrm{P}>0.05)$. All HBsAg-positive neonates were born to HBsAg-positive mothers with a rate of maternal transmission at $60.9 \%(14 / 23)$. HBeAg was detected in $21.7 \%$ (5/23) and in 7.1\% (1/14) of HBsAg-positive pregnant women and neonates, respectively.

Conclusions: Because of the high risk of developing chronic HBV infection at birth among infants born to HBsAg-positive mothers, administration of HBIG in combination with hepatitis B vaccine as post-exposure prophylaxis for such infants is of paramount importance. In addition, universal HBsAg screening of all pregnant women will greatly assist in reducing the maternal transmission of HBV in the country.
\end{abstract}

Key words: hepatitis B; seroprevalence; maternal transmission; Tripoli, Libya

J Infect Dev Ctries 2010; 4(3):168-170.

(Received 23 October 2009 - Accepted 23 October 2009)

Copyright $(92010$ El-Magrahe et al. This is an open-access article distributed under the Creative Commons Attribution License, which permits unrestricted use, distribution, and reproduction in any medium, provided the original work is properly cited.

\section{Introduction}

Hepatitis B virus (HBV), a DNA virus transmitted percutaneously, sexually and perinatally, affects 350-400 million individuals worldwide (1). HBV causes acute and chronic infections of the liver. Chronic HBV infection at birth occurs in approximately $90 \%$ of infants born to HBV surface antigen (HBsAg)- and hepatitis $\mathrm{B}$ e-antigen (HBeAg)-positive mothers (2,3). In addition, maternal transmission of $\mathrm{HBV}$ predisposes infected newborns to liver cirrhosis and hepatocellular carcinoma in young adulthood (4).

Data regarding the prevalence of $\mathrm{HBV}$ in pregnant women and maternal transmission of the virus in Libya are lacking. The aim of this study is to determine the seroprevalence of HBV infection in pregnant women in Tripoli, Libya, and to estimate the risk of perinatal transmission in women positive for $\mathrm{HBsAg}$.

\section{Materials and Methods}

From April 2001 to March 2002 blood samples from 1,500 pregnant women [aged $<21$ to $>35$ years $($ mean $=28$ years $)]$ and 1,500 cord blood samples of their neonates delivered at Tripoli Medical Center, Tripoli, Libya, were tested for HBsAg using ELISA techniques according to the manufacture's recommendations (Organon Teknika, WB Boxtel, The Netherlands). Blood samples positive for $\mathrm{HBsAg}$ were also tested for HBeAg. Informal consent was obtained from all participants in the study before blood samples were collected. None of the mothers reported being vaccinated against $\mathrm{HBV}$, or taking intravenous drugs. For statistical analysis, the Epi2000 software [Centers for Disease Control and Prevention (CDC), Atlanta, GA, USA] was employed. $\mathrm{P}$-values were calculated using Chi-squares test and a $\mathrm{P}$-value $<0.05$ was considered statistically significant. 


\section{Results}

HBsAg was detected in $23(1.5 \%)$ pregnant women and in $14(0.9 \%)$ neonates. Although HBsAg was detected at higher rate in pregnant women aged > 25 years $[1.8 \%(22 / 1,235)]$ than in pregnant women aged $<25$ years $[0.4 \%(1 / 265)]$, the difference was not statistically significant $(\mathrm{P}>0.05)$. All $\mathrm{HBsAg}$ positive neonates were born to HBsAg-positive mothers with a rate of maternal transmission at $60.9 \%$ $(14 / 23)$. HBeAg was detected in $21.7 \%(5 / 23)$ and $7.1(1 / 14)$ of HBsAg-positive pregnant women and HBsAg-positive neonates, respectively.

\section{Discussion}

Hepatitis B virus and hepatitis C virus are responsible for the majority of chronic liver disease cases and leading causes of hepatocellular carcinoma in Libya (5). Studies conducted during the nineties of last century have reported $\mathrm{HBsAg}$ seroprevalence rates between $4.3-4.6 \%$ among the Libyan population $(6,7)$. Recently, a general population-based HBV seroprevalence nationwide survey performed in Libya (65,300 participants) reported a seroprevalence rate of $2.2 \%$ for $\mathrm{HBsAg}$ (8). We detected HBsAg in $1.5 \%$ of the pregnant women examined, which is lower than the rate reported in the general Libyan population. This result could be due to the fact that HBV infection in Libya is related, among other factors, to the male gender (5).

Also, the prevalence of seropositive $\mathrm{HBsAg}$ among pregnant women in the present study is low in comparison with the prevalence rates reported from the North Africa and the Middle East regions. HBsAg seroprevalence rates in pregnant women of $4 \%, 5.6 \%$ and $15.3 \%$ have been reported from the neighboring countries Tunisia (9), Sudan (10) and Egypt (11), respectively. Studies from the Middle East reported rates of $4.3 \%$ from Jordan (12) and 2.4\% from Saudi Arabia (13). High prevalence rates of $\mathrm{HBsAg}$ were also reported from Ghana (10.5\%) (14), Nigeria $(10.3 \%)(15)$ and Yemen (13.2\%) (16). Geographical differences may explain the variation in seroprevalence rates of $\mathrm{HBsAg}$ among pregnant women from different countries. Studies have shown that variation may even exist among regions of the same country $(13,17)$.

Several studies reported that HBV infection in pregnant women increased with age $(16,17)$. In the present investigation no significant difference in the prevalence of $\mathrm{HBsAg}$ in different age groups was observed. Similar results were reported by other investigators $(10,14,17)$.
Worldwide perinatal transmission of $\mathrm{HBV}$ is an important route of infection. Studies have shown vertical transmission of HBsAg between 10 and $85 \%$ (18). Onakewhor et al. (19) examined 320 mother and neonatal cord blood pairs, and reported neonatal seroprevalence of $\mathrm{HBsAg}$ of $0.96 \%$ and vertical transmission rate of $42.9 \%$. We examined 1,500 mother and neonatal cord blood pairs and found a closely similar seroprevalence rate of HBsAg among the neonates examined $(0.9 \%)$; however, the vertical transmission rate was higher in the present study $(60.9 \%)$. Badawy and El-Salahy (11) reported a rate of materno-fetal transmission in $51.8 \%$ of $\mathrm{HBsAg}$ positive women in Egypt. Lower perinatal transmission rates of HBV have been reported from Bangladesh (12.8\%) (20) and India (17\%) (21). Reported variable vertical transmission rates from HBsAg-mothers to their infants depend on several factors, including viral load, HBV variants and sensitivity and accuracy of diagnostic tests (22).

$\mathrm{HBeAg}$ was detected in $21.7 \%$ (5/23) of HBsAgpositive mothers. This marker correlates with level of infectivity; an $\mathrm{HBeAg}$-positive pregnant mother is most likely to transmit the virus to the fetus. In this study, $\mathrm{HBeAg}$ was detected only in one $(7.1 \%)$ HBsAg-positive neonate. Nas et al. (23) detected $\mathrm{HBeAg}$ in $7.5 \%$ of $\mathrm{HBsAg}$-positive pregnant women in Ankara, Turkey. On the other hand, Al-Shamahy (16) reported a rate of $60 \%$ for $\mathrm{HBeAg}$ among HBsAg-positive mothers in Sana'a, Yemen.

In Libya, HBV vaccine has been provided since 1993 free of charge to all newborns. In 2000 the Secretary of Health recommended anti-natal screening and in 2005 a mass HBV vaccination campaign was carried out targeting adolescents born in 1990 to 1992 (5). Such actions doubtlessly will contribute to the reduction of $\mathrm{HBV}$ in the future in Libya. However, chronic HBV infection remains a major health care problem in Libya (5). This study showed a high rate ( $>60 \%$ ) of maternal transmission of HBV among HBsAg-positive mothers in Tripoli. Because of the high risk of developing chronic HBV infection at birth among infants born to $\mathrm{HBsAg}$ positive mothers, the administration of HBIG in combination with hepatitis B vaccine as postexposure prophylaxis for such infants is of paramount importance. In addition, universal HBsAg screening of all pregnant women will greatly assist in reducing the maternal transmission of $\mathrm{HBV}$ in the country. 


\section{References}

1. Dienstag JL (2008) Hepatitis B Virus Infection. N Engl J Med 359: 1486-1500.

2. Hyams KC (1995) Risk of chronicity following acute hepatitis B virus infection. Clin Infect Dis 20: 992-1000.

3. McMahon BJ, Alward WLM, Hall DB, Heyward WL, Bender TR, Francis DP, Maynard JE (1985) Acute hepatitis $B$ virus infection: relation of age to the clinical expression of disease and subsequent development of the carrier state. $\mathbf{J}$ Infect Dis 151: 599-603.

4. Sookoian S (2007) Hepatitis B virus and pregnancy. Hepatitis B Annual 4: 12-23. (http://www.hepatitisbannual.org).

5. Elzouki A-N (2008) Hepatitis B infection in Libya: the magnitude of the problem. Libyan J Infect Dis 2: 20-25.

6. Daw MA, Alsayed ZF, Ashawish MM, Elmasrati H, Elassabie H, Ghenghesh KS (1994) Prevalence of hepatitis $B$ virus among the Libyan population. 3rd International Conference of the Hospital Infection Society, London, UK.

7. Ghashout S, Ghenghesh KS, Elghul MT (1998) Hepatitis C virus in blood donors and drug addicts in Tripoli-Libya. 2nd European Congress on Tropical Medicine, Liverpool, UK.

8. Elzouki A-N, Esmeo M-N, Samod M, Abonaja A, Alagi B, Daw M (2006) Prevalence of hepatitis B and C infection in Libya: a population-based nationwide seropepidemiological study. J Gastroenterol Hepatol 21(Suppl): A114-A115.

9. Hannachi N, Bahri O, Mhalla S, Marzouk M, Sadraoui A, Belguith A, Triki H, Boukadida J (2008) Hepatitis B virus infection in Tunisian pregnant women: Risk factors and viral DNA levels in $\mathrm{HBe}$ antigen negative women (in French). Pathologie Biologie (in press).

10. Elsheikh RM, Daak AA, Elsheikh MA, Karsany MS, Adam I (2007) Hepatitis B virus and hepatitis C virus in pregnant Sudanese women. Virol J 4: 104. (http://www.virologyj.com/content/4/1/104).

11. Badawy HA, El-Salahy E (2000) Materno-foetal transmission of hepatitis B infection. J Egypt Public Health Assoc 75: 357-67.

12. Batayneh N, Bdour S (2002) Risk of perinatal transmission of hepatitis B virus in Jordan. Infect Dis Obstet Gynecol 10: 127-32.

13. Khalil MKM, Al-Mazrou YY, Al-Jeffri M, Al-Ghamdi YS, Mishkhas A, Bakhsh M, Eisa M, Nageeb M, Tumsah S (2005) Serosurvey of hepatitis B surface antigen in pregnant Saudi women. Eastern Mediterran Health J 11: 640-47.

14. Damale NKR, Lassey AT, Bekoe V (2005) Hepatitis B virus seroprevalence among parturients in Accra, Ghana. Intern J Gynecol and Obstet 90: 240-41.

15. Onuzulike N, Ogueri EO (2007) Sero-prevalence of hepatitis B surface antigen ( $\mathrm{HBsAg}$ ) in pregnant women in Owerri, Imo State of Nigeria. Res J Biol Sci 2: 178-82.

16. Al-Shamahy HA (2000) Prevalence of hepatitis B surface antigen and risk factors of $\mathrm{HBV}$ infection in a sample of healthy mothers and their infants in Sana'a, Yemen. Ann Saudi Med 20: 464-67.

17. Vázquez-Martínez JL, Coreño-Juárez MO, Montaño-Estrada LF, Attlan M, Gómez-Dantés H (2003) Seroprevalence of hepatitis B in pregnant women in Mexico. Salud Publica Mex 45: 165-70.

18. Beasley RP, Trepo C, Stevenson CE (1977) The c-antigen and vertical transmission of hepatitis B surface antigen. Am J Epidemiol 105: 94-98.
19. Onakewhor JUE, Offor E, Okonofua FE (2001) Maternal and neonatal seroprevalence of hepatitis B surface antigen (HBsAg) in Benin City, Nigeria. J Obstet Gynaecol 21: 58386.

20. Rumi MA, Begum K, Hassan MS, Hasan SM, Azam MG, Hasan KN, Shirin M, Khan AK (1998) Detection of hepatitis B surface antigen in pregnant women attending a public hospital for delivery: implication for vaccination strategy in Bangladesh. Am J Trop Med Hyg 59: 318-22.

21. Chakravarti A, Rawat D, Jain M (2005) A study of the perinatal transmission of the hepatitis B virus. Indian J Med Microbiol 23: 128-30.

22. Seow H.-F (1999) Hepatitis B and C in pregnancy. Curr Obstetr Gynaecol 9: 216-23.

23. Nas T, Taner MZ, Y1ldiz A (1999) Seroprevalence of syphilis, human immunodeficiency virus type-1, and hepatitis B virus infections among pregnant women in Turkey. Intern J Gynecol Obstet 66: 171-72.

\section{Corresponding author}

Professor Khalifa Sifaw Ghenghesh, MSc, PhD, DipBact Department of Microbiology and Immunology

Faculty of Medicine

Al-Fateh University for Medical Sciences

PO Box 80013

Tripoli-Libya

Email: ghenghesh_micro@yahoo.com

Conflict of interest: No conflict of interests is declared. 